\title{
Review of Different Methods for Optimal Placement of Phasor Measurement Unit on the Power System Network
}

\author{
Ademola Abdulkareem, Divine Ogbe, Tobiloba Somefun* \\ Department of Electrical and Information Engineering, Covenant University, Ota, 112107, Nigeria
}

\author{
A R T I C L E IN F O \\ Article history: \\ Received: 06 August, 2020 \\ Accepted: 11 November, 2020 \\ Online: 14 December, 2020
}

Keywords:

Phasor Measurement Unit

Voltage Phasor

Current Phasor

Global Positioning System

Optimal PMU Placement

Power System Observability

\begin{abstract}
A B S T R A C T
Phasor Measurement Unit (PMU) is an integral device for tracking, protection, and regulation of the power network. PMU gives synchronised calculations of actual-time data for voltage phasor, current phasor, and the frequency. Placing PMU in every node to observe the power network is not realistic from an economic standpoint and even for big data management. Thus, raising the number of PMUs in the node network to achieve optimum monitoring of the power network is a mandatory issue. In tracking the problem of optimal PMU placement, various methods have been proposed by various researchers in recent times. To facilitate understanding among the various approaches, this study classified the existing methods into two headings; heuristic and mathematical(conventional)methods. The study discusses the different existing optimisation approaches used to solve the optimal PMU placement problems. The benefits, as well as the drawbacks of each approach, is thoroughly examined and wind up the discussion that the heuristic approach is a fast knowledge-based methodology, which was used as the optimization solver for the IEEE 14, 30 and Nigeria national grid 28 and 52 bus system.
\end{abstract}

\section{Introduction}

Phasor measurement unit is an electrical instrument that measures the phase angle and magnitude of current and voltage in the power network system, using a synchronised time source provided by global positioning system, which can provide accuracy up to one microsecond [1]. To decide the condition of a power network, the estimations of the state variables (phase angles and voltage magnitude), of all system nodes should be known. Realising these values helps to calculate the flow of real and reactive power in the power network. It will be very strenuous to consider system nodes one of after the other most especial a large system, this is one area in which intelligent devices find application [2] in this case PMU estimations solve the problem effortlessly.

At a particular period, the voltage phase angle and magnitude and current sinusoidal waveforms are expressed as real and imaginary numbers that are known as a phasor. The value of the magnitude is dependent on the amplitude of the sinusoidal waveform, while the phase angle is gotten relying on the time position as presented in the figures. Figure 1a shows the sinusoidal

*Corresponding Author: Tobiloba Somefun, km 10, Idiroko Road, Canaanland Covenant University, +2348037632337, Email:

tobi.shomefun@covenantuniversity.edu.ng

www.astesi.com

https://dx.doi.org/10.25046/aj0506130 waveform is behind as for the cosine reference, as it is behind, the phase angle will be negative, though, in Figure 1b, the sinusoidal waveform is ahead as for the cosine reference. Subsequently, the phase angle is positive. Since the phasor measurement unit is provided with the global positioning system, every phasor estimation is time-tagged, consequently, permitting phasor estimations gotten from the phasor measurement units in different positions in a system to synchronise.

PMU firstly receives signals in analogue form. The signal being received contains estimated voltages and currents from current and voltage transformer. The anti-aliasing filter then used in eliminating high-frequency factors surpassing the sampling limit of Nyquist. It will, therefore, suppress the frequency factors that exceed the Nyquist sampling rate. The phase-locked oscillator divides the global positioning system one pulse each second into the needed number of pulses as regards the sampling of the waveform. Through the use of a 16-piece accuracy analogue to a digital converter, the input signals will be digitised at sampling moments when the time signals are sampled from the phase-locked oscillator before feeding it to the phasor microprocessor. The microprocessor resamples the signals from the digitised sample information and estimates the positive succession. Then the 
approximate phasor is time-stepped before being moved using modems to a communication medium [3].

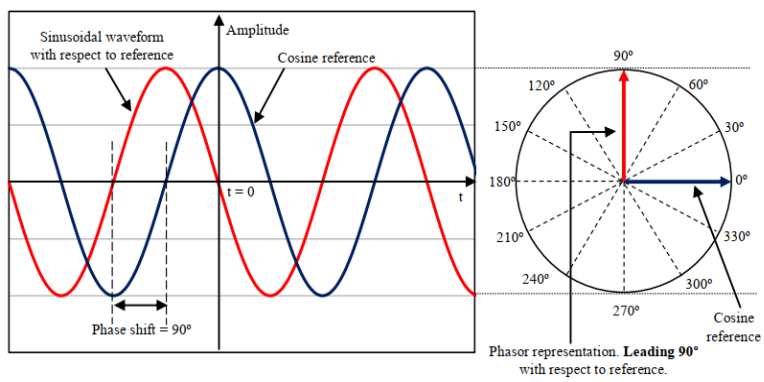

Figure 1: (a) phasor representation. $-90^{\circ}$ regarding cosine reference [3]

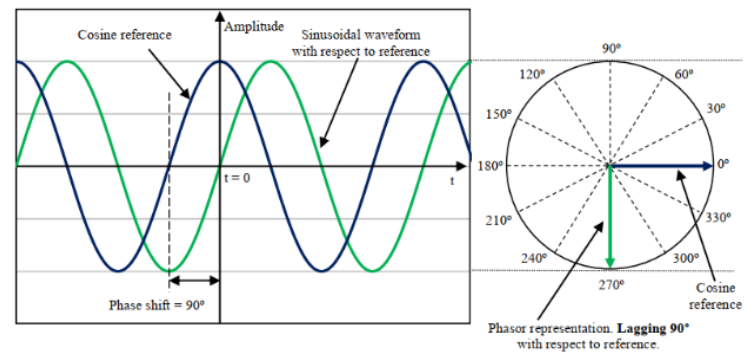

Figure 1: (b) phasor representation. $90^{\circ}$ regarding cosine reference [3]

\section{Optimal PMU Placement Problem Formulation}

There are two main performances used in the analysis for observing power system; they are numerical observability and topological observability [4]. Numerical observability suffers from a lot of matrix computations; thus, it is not advisable to employ them for analysing power systems, especially large ones. Topological observability of a system is achieved when a full rank of traversing the tree is obtained. Some simplified and improved effective rules when topologically analysing a power system are illustrated below:

Rule 1: For a PMU-installed node, voltage phasor and the connecting branches current phasor are known as demonstrated in Figure 2. This measurement is known as direct measurement. In Figure 2, PMU is installed in node 1; consequently, the voltage phasor of the node is known, and the current phasor of the connecting line is also known following the first rule.

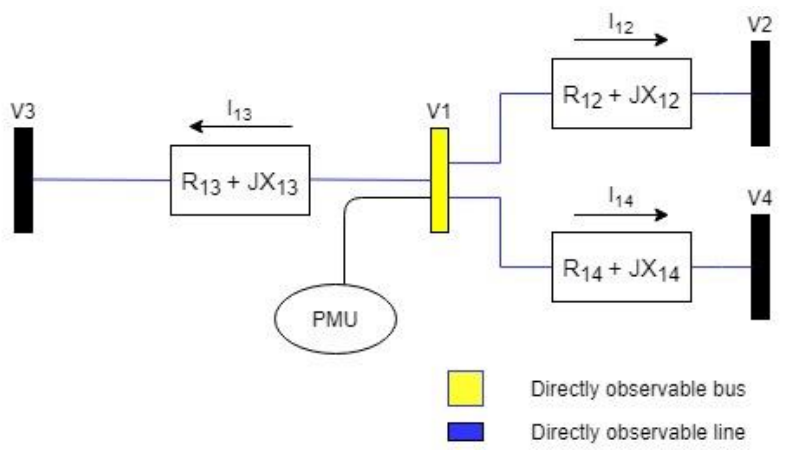

Figure 2: illustrating Direct measurement Rule 1

Rule 2: When the voltage phasor is known, and the current phasor at one end of the branch is also known, it guarantees that the other end is observable by determining the voltage phasor, as illustrated in Figure 3. This type of measurement is known as pseudo-measurement.

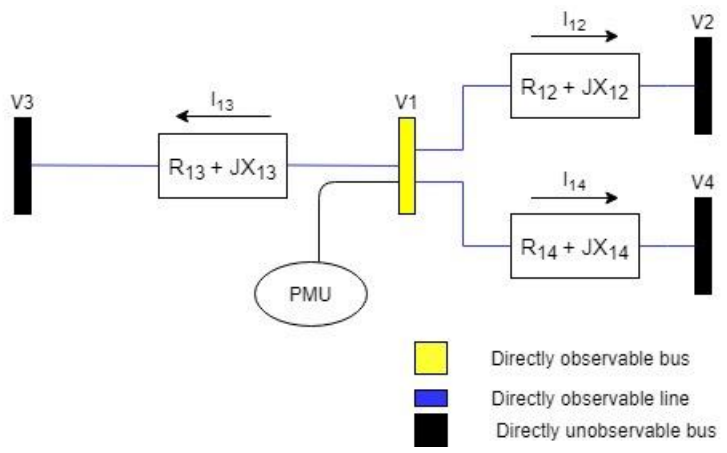

Figure 3: illustrating pseudo-measurement Rule 2

Since the value of the current phasors of the lines connected to node 1 is known, the value of the other nodes can be solved for by utilising Ohms law.

$$
\begin{gathered}
I_{12}=\frac{V_{1}-V_{2}}{R_{12}+j X_{12}} \\
V_{2}=V_{1}-I_{12}\left(R_{12}+j X_{12}\right) \\
I_{13}=\frac{V_{1}-V_{3}}{R_{13}+j X_{13}} \\
V_{3}=V_{1}-I_{13}\left(R_{13}+j X_{13}\right) \\
I_{41}=\frac{V_{4}-V_{1}}{R_{14}+j X_{14}} \\
V_{4}=V_{1}+I_{41}\left(R_{41}+j X_{41}\right)
\end{gathered}
$$

Rule 3: In a case where the voltage phasor for both ends is known, the current phasor of the connecting branch can be gotten as shown in Figure 4. Knowing the voltage phasor of node-1 and node- 2 , the current phasor of the connecting line can be calculated using Ohm's law.

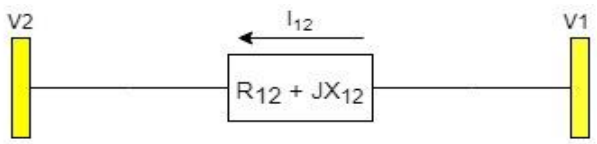

Directly observable bus

Figure 4: Illustrating observability of the branch current for rule 3

$$
I_{12}=\frac{V_{1}-V_{2}}{R_{12}+j X_{12}}
$$

Rule 4: For a zero-injection node, knowing all the current of all connected branches, except one, calculating the current for the unknown branch can be achieved using Kirchhoff current law (KCL) this rule is demonstrated in Figure 5. node-3 is the zeroinjection node, and current phasor of every branch is known except the current for the branch between node- 3 and node- 4 .

Rule 5: For a zero-injection node where the voltage phasor is not known, if all the neighbouring nodes are known, the zeroinjection node can be known through calculations, as shown in Figure 6. In the diagram, node- 3 is the zero-injection node and the 
voltages for the neighbouring nodes is known. By using node calculations, the voltage for node- 3 is known.

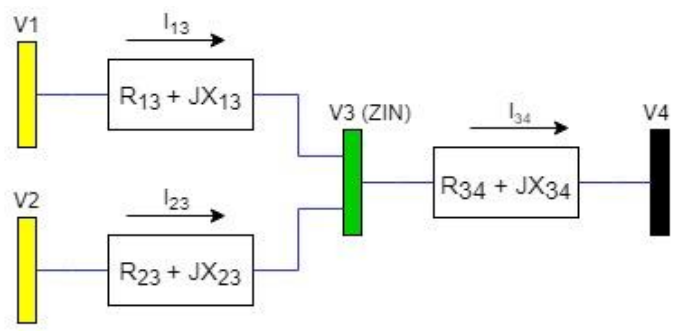

Zero injection node

Directly observable bus

Unbservable bus

Figure 5: Model observability of zero-injection node for rule 4

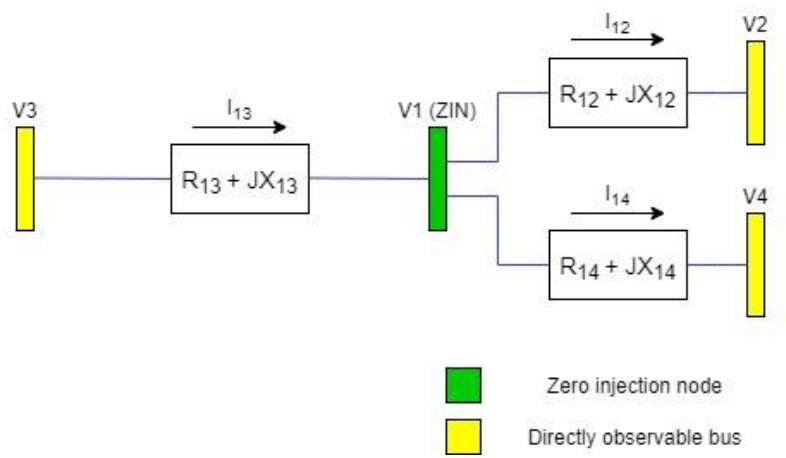

Figure 6 Modelling unobservable ZIN rule 5

$$
\begin{gathered}
V_{3}=V_{1}-I_{13}\left(R_{13}+j X_{13}\right) \\
V_{3}=V_{2}+I_{32}\left(R_{32}+j X_{32}\right. \\
V_{3}=V_{4}+I_{34}\left(R_{34}+j X_{34}\right) \\
0=I_{12}-I_{32}-I_{24}
\end{gathered}
$$

Rule 6: For a group of neighboring zero-injection nodes that are not observable because the voltages are not known, but the neighboring nodes connected to the group of zero injection nodes are known. The unknown voltage phasors of the zero-injection nodes can be made known by using both Kirchhoff's current and voltage laws as illustrated in Figure 7. In this figure, the voltage of node- 3 and node- 4 , but the voltages of the nodes connected to them are known.

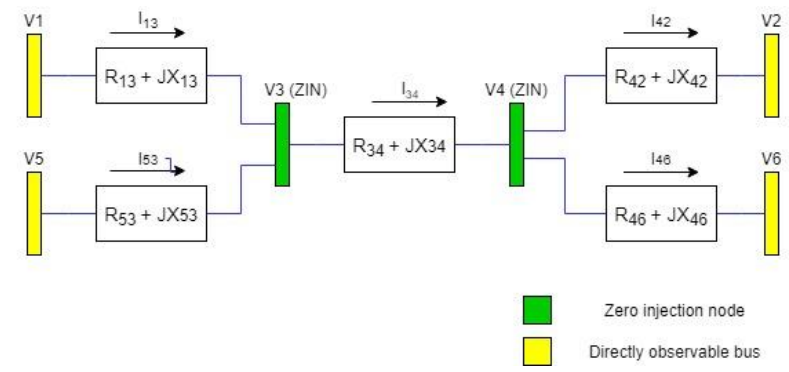

Figure 7 Modelling unobservable ZINs rule 6

Minimum number of PMU: One of the purposes of the optimal PMU placement problem is to resolve the minimum number of PMUs needed for a power system and their right allocation to make sure that the system is totally observable. This objective can be represented mathematically as shown:

$$
\begin{aligned}
& \sum_{\mathrm{i}}^{\mathrm{N} \text { nodes }} \mathrm{A}_{\mathrm{ij}} \\
& \text { s.t } B * A \geq 1 \\
& I=[111 \ldots \ldots 1]_{N X 1}^{T} \\
& A(i)=\left\{\begin{array}{c}
1 \quad \text { if PMU is installed on node } i \\
0 \quad \text { if PMU is not installed on node } i
\end{array}\right. \\
& B(i, j)=\left\{\begin{array}{rr}
1 & \text { if } i=j \\
1 & \text { if nodes } i \text { and } j \text { are joined } \\
0 \text { if nodes } i \text { and } j \text { are not joined }
\end{array}\right.
\end{aligned}
$$

\section{Placement Methods}

Several methods have been deployed for optimal location on power system network in different regards such as distributed generators and PMU [5,6]; in this section, several of the methods used to optimally site PMU are extensively reviewed.

\subsection{Conventional Method}

Two of the conventional methods that have been reported in previous studies are discussed under this subsection.

\subsubsection{Integer Linear Programming (ILP)}

Integer Linear Programming methods, also recognised as binary integer programming, considering both the system's injection and power measurement as well as PMU error calculation by state estimation. Integer linear programming algorithm is based on the individual vectors derived from the adjacency matrix of the transverse tree [7]. Upon decomposition, the PMUs are positioned ideally in the networks utilising the integer linear programming principle to reduce the deployment rate. Two types of ILP models are mixed integer linear programming (MILP) and binary integer linear programming (BILP) [8].

\subsubsection{Integer Quadratic Programming (IQP)}

Integer quadratic programming utilises the connectivity matrix that reflects the topology of the system to define the optimal PMU placement (OPP) problem. The quadratic function's objectives were structured, taking into account linear constraints and the vector of integer values. The method will decrease the number of PMUs by providing full network observability in standard operations as well as in outages [8].

In [9], the authors discussed factors that affect calculation precision, including measurements inconsistencies, number of PMU measurements, and quasi-power measurements implementation. Quasi-power uncertainty is determined by the propagation concept of uncertainty, and the optimum location of PMU is calculated by integer quadratic linear programming. Various types of state variables as well exhibited different sensitivities to different measurements [10].

\subsubsection{Drawbacks of Conventional Methods}

Usually, the conventional technique is utilised to model a network when the network is not so complex. Also, conventional 
technique takes more computational time when compared with Heuristic techniques to solve a complicated network problem.

\subsection{Heuristic Methods}

Most of the Heuristic Methods that have been reported in previous studies are discussed under this subsection.

\subsubsection{Genetic Algorithm}

The foundation of genetic algorithm is to model natural selection which has no requirement for secondary functions like derivatives calculation. Some of the advantages of genetic algorithm which makes it more applicable to OPP problems are: the likelihood of the local minimum being trapped is reduced, Calculations are decreased from one state to the other, and the fitness assessment of each sequence directs the search [11].

In [12], they investigated optimally placing PMUs and communication links for distributed state estimation in distribution networks. They combined integer linear programming and genetic algorithm to find the least number of PMUs in a distribution network. A distributed state estimation system segmenting technique is created to minimise the burden it takes to compute and communicate [13]. The aim of the partitions is to balance the number of buses in subareas. By turning the network segmenting into the problem of assigning a centralised bus of each subarea, the scale-balanced partitioning scheme between subareas is obtained by applying genetic algorithms.

\subsubsection{Particle Swarm Optimisation}

Particle swarm optimisation is a similar technique to genetic algorithm, where population solutions are randomly assigned to a system firstly [14]. In [15], the authors described particles as entities that are hovering through multidimensions in space. For every particle, the best location is determined by the fittest position faced by that particle and its neighbouring particles. The process of the particle swarm optimisation begins with a primary point and velocity for every particle, where the velocity of each particle is restricted by reasons of not hovering in unusable space as well as overflowing forbiddance [16].

\subsubsection{Tabu Search}

The Tabu search algorithm is a combinatorial method, and it combines techniques such as conventional method and heuristic method. This method is majorly used in solving combinatorial optimisation problems in covering and scheduling. Tabu lists, which is a major element of tabu search, consists of numbers of states visited in recent times and unwanted states. Another major element of tabu search is the state definition and the encompassing area. The tabu search resets when it does not converge [17].

In [18], the authors solved the optimal PMU placement problem and achieved maximum observability of a system and maximum redundancy by utilising tabu search-based linear state estimation model [19]. This quick technique of topological observability analysis required a loss simulation function relying on the matrix of incidence to solve the optimal PMU placement problem. This technique also concerns the convenience and high speed to monitorable power network by manipulating integer numbers [20].

\subsubsection{Differential Evolution}

The method of differential evolution (DE) uses elements such as $\mathrm{N}$-dimensional vectors to reduce progressing space functions. Mutation, fusion and choice are the key functions used in the global optimising process. Differential evolution approach is utilised extensively in various problems of cost function including multimodal, non-differentiable, and nonlinear functions. Certain advantages of this method include simultaneous computations, simple use, and strong synchronisation properties [21].

The researchers introduced multi-objective optimal PMU placement in [22] utilising a non-dominating filtering DE technique, that is an organic synthesis of the nondominated filtering procedure and DE technique Pareto. This theory put into consideration total measurement reliability and voluntary PMU failure to achieve complete observability of the network in addition to finding a solution to the optimal PMU placement problem [3] Using the differential evolution technique obtained from genetic algorithm contributed to the suggested method for the nondominated sorting differential evolution algorithm. It was stated that obtaining a particular and absolute Pareto front and having several Pareto ideal solutions was the improvement of this method.

\subsubsection{Simulated Annealing}

The simulated annealing method solves complex combinatorial optimisation where the existing solution is changed arbitrarily. The new changed solution is the worst change with a decreased probability as computing continues. The ideal outcome for a major problem of combinatorial optimisation requires an effective disturbance framework, cost function, space for the solution, and cooling plan for the simulated annealing to solve. Simulated annealing can be considered adequate by looking for a large-scale network and achieving good speed in seeking an ideal or near-ideal solution [23]

Authors in [24], investigated effective use of different PMU estimated values and exposure to extremely critical network data were put into consideration for the ideal deployment of PMUs to make the power system fully observable. A topological observability formulation based on the incidence matrix evaluated the original PMU arrangement to have a network with complete observability.

\subsubsection{Ant Colony Optimization}

A further concept used to present an optimisation problem solution is ant colony optimisation, which originally utilises the ant population. The function of the ant colony was to travel across neighbouring states of the problem by implementing an ideal controller for the stochastic local resolution, resulting in solving optimising problem. Evaporation of the pheromone trace and action of the daemon are procedures in ant colony optimisation. The use of ant colony optimisation to determine good paths across graphs will decrease computational issues [25].

Authors in [26], investigated on an enhanced ant colony optimization which was used to solve the ideal PMU placement problem for achieving a totally visible power network with the least number of PMUs and putting into consideration total measurement redundancy. The depth-first search as a conceptual 
graph approach was used to create an estimation tree to evaluate if the power system was observable [27].

\subsubsection{Iterated Local Search}

The key viewpoint of iterated local search is to search for a subspace characterised by local optimal solutions rather than the entire solution space. By using an integrated heuristic, there is a series of solutions where the best option is achieved if repeated arbitrary tests of the heuristic were to be used [28].

The optimal PMU placement method introduced in [29] involves two phases which included an initial PMU dispensation to reach a visible network by using an iterated local search to decide the least number of PMUs required to make a system fully visible. Page rank placement formulation is utilised in this approach to determine the significance of every bus.

\subsubsection{Mutual Information}

Taking into account not only access to a system with maximum observability but also analysing irregularities in the network states that utilised mutual information between PMUs measurements values and system states, and information theoretical method to solve optimal PMU placement problems was addressed in [30].

\subsubsection{Matrix Reduction}

For the problems of placing PMUs, a distribution matrix occurs, whereby the graph indicates the distribution scope whenever a station is placed in different locations. The problem level is determined by the range of the distribution. The approach of matrix reduction aims to establish ideal placement by increasing the matrix of incidence. Using a formulation based on removing digital data, the matrix reduction technique was proposed to achieve the least number of PMU to reach observability of the network completely and reduce the computation process [31].

\subsubsection{Imperialistic Competition Algorithm}

Imperialistic competition technique is a new technique formulated to solve optimal placement problems. Just like other heuristic techniques, imperialistic competition algorithm begins with a first population named country which is a colony of two types. Competitiveness of the countries brings about the minimal of the problem. The effectiveness of the Imperialistic competition technique in wide area optimisation was evaluated on test buses and as confirmed [32].

\subsubsection{Immune Genetic Algorithm}

The Immune Genetic Algorithm was utilised to proffer solution to placing the PMU optimally utilising three impact vaccinations to create a topologically measurable power system. The two measures that occur in an immune genetic algorithm approach to defend against viruses and bacteria are vaccines and immunity alternatives. The vaccination basis is the combination of technical knowledge and previous data about the optimal PMU placement problem. Two operators, namely, crossover and mutation, were considered by the immune genetic algorithm, which was utilised to maximise the tests [33].

\subsubsection{Biogeography Based Optimisation}

The biogeography-based technique is a mathematical model for the movement of species from one region, which is known as a habitat to another region, rising and extermination conditions of species. This technique is used to provide solutions to the problem of optimisation through complex performance environments and to improve the efficiency of species migration and integration into the habitat [34].

\subsubsection{Chemical Reaction Optimization}

To find a solution to the OPP problems, a newly formed heuristic approach named population-based chemical reaction technique was implemented. Through modelling the behaviour and movement of gases in a chemical reaction, reaching a low energy steady state was the key goal of the chemical reaction techniques, which sought to achieve the least free energy level. High performance was demonstrated by the application of the chemical reaction technique to metrics and practical problems [35].

Using a new heuristic approach called chemical reaction technique and simplified chemical reaction technique model, optimal PMU placement problem solved to achieve a completely measurable power network considering the system with and without zero-injection nodes [36].

\subsubsection{Artificial Bee Colony (ABC)}

Artificial bee colony technique's key motivating criteria are food resources path, food resources range, and food resources performance information [37]. The developed formulation could be used in solving unimodal and multi-modal mathematical optimization problems. Also, a multiple objective optimal PMU placement algorithm, called binary-coded was implemented in solving the optimal PMU placement problem and obtain the least quantity of PMU and highest possible network redundancy. Consideration was given to eventuality constraint conditions like a one-line outage, and arrangements of the least quantity of needed PMUs were determined [37].

\subsubsection{Bacteria Foraging Algorithm}

Biological evolution propensity towards animal exclusion with weak feeding strategies that work to find, handle, and consume food and spread the genes of animal performance in feeding approaches as they are more probable to achieve productive results. Weak foraging approaches after several years are either discarded or revamped [4]. Four operators utilised in the developed bacterial foraging algorithm were chemotaxis, swarming, reproduction, and removal and distribution [38].

\subsubsection{Cellular Learning Automata}

Cellular learning automata technique is cantered on the use of training automaton to change cellular automaton state conversion likelihood. This approach begins by determining each cell's inner condition. Instead, on the basis of cellular learning automata law, the strengthening signal for every training automata is calculated. Maintaining this operation will achieve the intended state [39].

In [29], a CLA approach was used to examine the integration of two opposing objective functions like the least number of PMUs and total measurement reliability to achieve a completely measurable power network. This research put into consideration 
the drawbacks of flexibility, including PMU/branch loss and traditional measurements and zero-injection nodes.

\subsubsection{Hybrid Methods}

Utilising a formulated hybrid genetic algorithm and simulated annealing, a solution was introduced in [38] to ideally place PMUs and remote terminal units for a large network of interconnected grids determined by a multiarea system state estimate. Using remote terminal units and conventional measurements, a PMU was incorporated into a power network to ensure the calculated state more precisely and reduce the expense of conventional measurement and cost of the remote terminal unit. Utility centre of one multiarea area to reach system measurements required a single PMU placement, as PMU measurement calculated the network node voltage. A criterion for the PMU was the node with the highest connecting line. The identification of faulty data was achieved by taking into account the vital measurement of each region.

A synthesis of least traverse tree technique with the optimised genetic algorithm is a hybrid method named MST-GA presented in [40] to achieve the least number of PMUs required to make a system fully observable and to consider optimising redundancy. This approach enhanced mutation operation taking into account grid topology information. As the key and side steps, fusion and mutation were used as an activity to create new entities, the outcome of the new analysis of this approach was a decrease in the number of PMUs required and a variety of solutions [41].

To easily capture the objectives and contributions of the previous studies with respect to methods/techniques deployed Table 1 is developed while Table 2 gives the comparison of conventional and heuristic methods with respect to four factors namely; the size of the problem, data requirement, accuracy, and effectiveness.

\subsubsection{Drawbacks of Heuristic Methods}

To efficiently implement the heuristic technique, it takes a specific level of expertise and experience $[4,8]$. Often these functionality specialists are difficult and costly to employ, particularly if they need domain knowledge. If the analysts are not included in the development, they may not be informed of the technical design constraints or why such design choices have been made [8]. Heuristic tests are poorly organized, and thus risk identifying one-time, low-priority issues. Lastly, heuristic assessments do not allow for an assessment of the performance of re-designs [3].

Table 1: Objectives and contributions of investigated studies

\begin{tabular}{|c|c|c|c|c|c|}
\hline $\begin{array}{l}\text { Author(s)/Reference } \\
\text { Number }\end{array}$ & Objective & Technique & Considerations & Gaps & Benefits \\
\hline $\begin{array}{l}\text { B. Mallikarjuna, P. } \\
\text { Gopakumar, M. J. B. } \\
\text { Reddy and D. K. } \\
\text { Mohanta [23] }\end{array}$ & $\begin{array}{l}\text { Ideal positioning of PMUs to allow } \\
\text { monitoring of incorrect data. simulated } \\
\text { annealing technique is implemented with } \\
\text { the stochastic new approach }\end{array}$ & $\begin{array}{l}\text { Simulated } \\
\text { Annealing }\end{array}$ & $\begin{array}{l}\text { detection of critical } \\
\text { measurements }\end{array}$ & $\begin{array}{lr}\text { Zero-injection } & \text { nodes } \\
(\text { ZIN)\& } & \text { Measurement } \\
\text { Redundancy was not } \\
\text { considered }\end{array}$ & $\begin{array}{l}\text { Observability of the power } \\
\text { network with critical } \\
\text { measurements }\end{array}$ \\
\hline $\begin{array}{l}\text { C. Margarida, K. } \\
\text { Xenia and V. Ana, } \\
\text { [42] }\end{array}$ & $\begin{array}{l}\text { Limiting the quantity of PMU allocation } \\
\text { utilising stochastic simulated annealing } \\
\text { algorithm }\end{array}$ & $\begin{array}{l}\text { Stochastic } \\
\text { Simulated } \\
\text { Annealing }\end{array}$ & $\begin{array}{l}\text { Detection of critical } \\
\text { measurements } \\
\text { introduced as a } \\
\text { consequence function }\end{array}$ & $\begin{array}{l}\text { The algorithm was not Line } \\
\text { loss, PMU the outage }\end{array}$ & $\begin{array}{l}\text { Detection of critical } \\
\text { measurements }\end{array}$ \\
\hline $\begin{array}{l}\text { Z. Zhida, Y. Hao, L. } \\
\text { Peng, L. Peng, K. } \\
\text { Xiangyu, W. } \\
\text { Jianzhong and W. } \\
\text { Chengshan [12] }\end{array}$ & $\begin{array}{l}\text { Reducing the quantity of PMUs, and } \\
\text { determining their geographical allocation, } \\
\text { achieving a total network of measurable } \\
\text { power. A genetic algorithm- } \\
\text { based procedure is used, and PMUs are } \\
\text { installed with current phasor } \\
\text { measurements as the maximum } \\
\text { quantity of simultaneous lines } \\
\text { are highlighted in all network nodes }\end{array}$ & $\begin{array}{l}\text { Genetic } \\
\text { Algorithm }\end{array}$ & $\begin{array}{l}\text { Connection of PMUs } \\
\text { with the number of } \\
\text { current phasors to be } \\
\text { calculated }\end{array}$ & $\begin{array}{l}\text { Quality of the result were } \\
\text { not documented. }\end{array}$ & $\begin{array}{l}\text { Needed channels for current } \\
\text { in the optimisation problem }\end{array}$ \\
\hline $\begin{array}{l}\text { C. Peng, H. Sun and } \\
\text { J. Guo. [43] }\end{array}$ & $\begin{array}{l}\text { Limiting the quantity of PMUs and } \\
\text { increasing the redundant measurements. In } \\
\text { place of one optimal solution, Pareto-ideal } \\
\text { solutions are presented }\end{array}$ & $\begin{array}{l}\text { Non- } \\
\text { Dominated } \\
\text { SortingGeneti } \\
\text { c Technique }\end{array}$ & $\begin{array}{l}\text { Zero-injection nodes \& } \\
\text { Measurement } \\
\text { Redundancy }\end{array}$ & $\begin{array}{l}\text { It was assumed that PMUs } \\
\text { capacity is limitless. PMU } \\
\text { channels limit was not } \\
\text { considered }\end{array}$ & $\begin{array}{lr}\text { Offering } & \text { Pareto-ideal } \\
\text { facade } & \text { forcontradictory } \\
\text { objectives, solution repair }\end{array}$ \\
\hline $\begin{array}{l}\text { S. M. Mazhari, H. } \\
\text { Monsef, H. Lesani } \\
\text { and A. Fereidunian } \\
{[39]}\end{array}$ & $\begin{array}{l}\text { A multi-objective ideal allocation to } \\
\text { minimise the quantity of PMUs and } \\
\text { increase the accuracy of measurements. } \\
\text { PMU allocation is also analysed by the } \\
\text { implementation of a standardised } \\
\text { observability function based on traditional } \\
\text { non-synchronous }\end{array}$ & $\begin{array}{l}\text { Cellular } \\
\text { Learning } \\
\text { Automata }\end{array}$ & $\begin{array}{l}\text { Traditional } \\
\text { measurements, PMU } \\
\text { failure, Branch loss }\end{array}$ & $\begin{array}{l}\text { This technique might not } \\
\text { give the least quantity of } \\
\text { PMUs to make the network } \\
\text { observable }\end{array}$ & $\begin{array}{l}\text { High } \\
\text { performanceinelectrical net } \\
\text { works on a large scale }\end{array}$ \\
\hline $\begin{array}{l}\text { A. A. Hany, Y. A. } \\
\text { Almoataz and V. } \\
\text { Mukherjee [25] }\end{array}$ & $\begin{array}{l}\text { The ABC definition is used to attain } \\
\text { the least quantity of PMUs to achieve a } \\
\text { total measurable power network, fulfilling } \\
\text { measurement redundancy }\end{array}$ & $\begin{array}{l}\text { Artificial Bee } \\
\text { Colony }\end{array}$ & $\begin{array}{l}\text { One branch loss, zero- } \\
\text { injection nodes }\end{array}$ & $\begin{array}{l}\text { The pheromone variation } \\
\text { span is restricted to interval } \\
{[0,-1] \text {, }}\end{array}$ & $\begin{array}{l}\text { System viability and } \\
\text { efficiency is shown by the } \\
\text { comparison of the } \\
\text { simulation results with the } \\
\text { previous works }\end{array}$ \\
\hline
\end{tabular}




\begin{tabular}{|c|c|c|c|c|c|}
\hline $\begin{array}{l}\text { N. C. Koutsoukis, N. } \\
\text { M. Manousakis, P. } \\
\text { S. Georgilakis and } \\
\text { G. N. Korres [19] }\end{array}$ & $\begin{array}{l}\text { Two contending purposes involving the } \\
\text { least quantity of PMU and maximum } \\
\text { redundancy on the network }\end{array}$ & Tabu Search & $\begin{array}{l}\text { Zero-injection nodes \& } \\
\text { Measurement } \\
\text { Redundancy }\end{array}$ & $\begin{array}{l}\text { Placement of PMU in } \\
\text { ZINwas not allowed in the } \\
\text { initialization. }\end{array}$ & $\begin{array}{l}\text { Optimal problems solved } \\
\text { with high precision and } \\
\text { reduced calculation }\end{array}$ \\
\hline $\begin{array}{l}\text { R. Ramachandran } \\
\text { and S. Karthick [44] }\end{array}$ & $\begin{array}{l}\text { Limiting the quantity of PMU placement } \\
\text { and developing a parallel tabu search } \\
\text { formulation }\end{array}$ & $\begin{array}{l}\text { Parallel Tabu } \\
\text { Search }\end{array}$ & $\begin{array}{l}\text { Communication } \\
\text { restraint, Zero-injection } \\
\text { nodes, and matrix } \\
\text { condition of the state } \\
\text { estimations }\end{array}$ & $\begin{array}{l}\text { Traditional measurements, } \\
\text { PMU failure, Branch loss } \\
\text { was not considered }\end{array}$ & Reduced calculation period \\
\hline $\begin{array}{l}\text { M. Nazari-Heris and } \\
\text { B. Mohammadi- } \\
\text { Ivatloo [4] }\end{array}$ & $\begin{array}{l}\text { Two contending purposes involving the } \\
\text { least quantity of PMU and maximum } \\
\text { redundancy }\end{array}$ & $\begin{array}{l}\text { Clonal } \\
\text { Algorithm }\end{array}$ & Total redundancy & $\begin{array}{lrr}\text { ZIN } & \text { enhancement } & \text { of } \\
\text { secondary voltage } & \text { control } \\
\text { operation } & \text { was } & \text { not } \\
\text { considered } & & \end{array}$ & $\begin{array}{l}\text { Maximum velocity of the } \\
\text { procedure, achieving } \\
\text { practical schemes }\end{array}$ \\
\hline $\begin{array}{l}\text { M. Zhou, V. } \\
\text { Centeno, A. Phadke, } \\
\text { Y. Hu, D. Novosel } \\
\text { and H. Volskis [31] }\end{array}$ & $\begin{array}{l}\text { Reducing the quantity of PMUs. Utilising } \\
\text { pre-processing techniques and providing } \\
\text { solutions using mathematical based } \\
\text { methods }\end{array}$ & $\begin{array}{l}\text { Matrix } \\
\text { Reduction }\end{array}$ & $\begin{array}{l}\text { Computer-generated } \\
\text { data removal, Pre- } \\
\text { processing technique and } \\
\text { matrix reduction } \\
\text { procedure, utilising } \\
\text { Lagrangian relaxation }\end{array}$ & $\begin{array}{l}\text { Quality assessment was not } \\
\text { recorded because there was } \\
\text { no other tested optimal } \\
\text { placement set for the } \\
\text { Brazilian network }\end{array}$ & $\begin{array}{l}\text { Minimising the size of } \\
\text { allocation model and the } \\
\text { calculation exertion, } \\
\text { employed in a large-scale } \\
\text { network }\end{array}$ \\
\hline $\begin{array}{l}\text { S. Md, I. H. Md, M. } \\
\text { Abido, A.-F. Taher } \\
\text { and M. A.H [15] }\end{array}$ & $\begin{array}{l}\text { Limiting the quantity of PMUs so as the } \\
\text { power network can be fully observed. } \\
\text { Developing a hybrid technique based on } \\
\text { binary particle swarm optimisation }\end{array}$ & $\begin{array}{l}\text { Binary Particle } \\
\text { Swarm } \\
\text { Optimisation }\end{array}$ & $\begin{array}{l}\text { Increasing redundancy in } \\
\text { the power network, one } \\
\text { PMU and Multi-PMU } \\
\text { failure }\end{array}$ & $\begin{array}{l}\text { loss of PMU and branch } \\
\text { loss were ignored }\end{array}$ & $\begin{array}{l}\text { Maximum velocity of the } \\
\text { procedure and reduced } \\
\text { calculation period }\end{array}$ \\
\hline $\begin{array}{l}\text { A. A. Hany, Y. A. } \\
\text { Almoataz and V. } \\
\text { Mukherjee. [25] }\end{array}$ & $\begin{array}{l}\text { Reducing the quantity of PMU in the } \\
\text { system. Developing an improved ant } \\
\text { colony technique }\end{array}$ & $\begin{array}{l}\text { Ant Colony } \\
\text { Optimisation }\end{array}$ & $\begin{array}{l}\text { High redundant } \\
\text { measurements in the } \\
\text { system }\end{array}$ & $\begin{array}{l}\text { The pheromone variation } \\
\text { span is restricted to interval } \\
{[0,-1] \text {, }}\end{array}$ & $\begin{array}{l}\text { Avoiding inactivity } \\
\text { behaviour and elevated } \\
\text { velocity of the procedure, } \\
\text { employing a graph theoretic } \\
\text { technique }\end{array}$ \\
\hline $\begin{array}{l}\text { S. S. Noureen, V. } \\
\text { Roy and S. B. Bayne } \\
{[8]}\end{array}$ & $\begin{array}{l}\text { Reducing the quantity of PMU and remote } \\
\text { terminal units with critical measurements } \\
\text { free }\end{array}$ & $\begin{array}{l}\text { Hybrid } \\
\text { Genetic } \\
\text { Algorithm and } \\
\text { Simulated } \\
\text { Annealing }\end{array}$ & $\begin{array}{l}\text { Traditional measurement } \\
\text { and RTU faulty data } \\
\text { recognition, one-line } \\
\text { outage }\end{array}$ & $\begin{array}{l}\text { Fault monitoring, ZIN was } \\
\text { ignored }\end{array}$ & $\begin{array}{l}\text { Relevant to existing power } \\
\text { networks observed utilising } \\
\text { remote terminal units }\end{array}$ \\
\hline $\begin{array}{l}\text { S. Mahapatra, S. } \\
\text { Pandab and S. C. } \\
\text { Swaina [33] }\end{array}$ & $\begin{array}{l}\text { Limiting the quantity of PMU placement } \\
\text { and increasing measurements redundancy, } \\
\text { taking considerations of traditional } \\
\text { measurements }\end{array}$ & $\begin{array}{l}\text { Bacterial } \\
\text { Foraging } \\
\text { Algorithm }\end{array}$ & $\begin{array}{l}\text { Total redundancy } \\
\text { zero-injection nodes }\end{array}$ & $\begin{array}{l}\text { The linear model could not } \\
\text { correctly depict complex } \\
\text { dynamics of the network, } \\
\text { particularly in disturbances. }\end{array}$ & $\begin{array}{lll}\text { Appropriate for } & \text { existing } \\
\text { power networks } & \text { due to } \\
\text { modelling } & \text { standard } \\
\text { measurement } & \end{array}$ \\
\hline $\begin{array}{l}\text { M. N. Seyyed and } \\
\text { M. Javad [21] }\end{array}$ & $\begin{array}{l}\text { Limiting means square error by achieving } \\
\text { the least quantity of PMUs, with or } \\
\text { without the presence of standard } \\
\text { measurement }\end{array}$ & $\begin{array}{l}\text { Differential } \\
\text { Evolution }\end{array}$ & $\begin{array}{l}\text { Normal measurement } \\
\text { least square error of state } \\
\text { estimate }\end{array}$ & $\begin{array}{l}\text { Fault monitoring, Zero- } \\
\text { injection nodes was ignored }\end{array}$ & $\begin{array}{l}\text { The precise, fast and } \\
\text { straightforward procedure, } \\
\text { ability to employ in multiple } \\
\text { objectives problem }\end{array}$ \\
\hline $\begin{array}{l}\text { B. Rohit and B. } \\
\text { Biplab [45] }\end{array}$ & $\begin{array}{l}\text { Limiting the cost of installation of } \\
\text { Mismodelling dissimilar cost of PMUs for } \\
\text { various nodes }\end{array}$ & $\begin{array}{l}\text { Particle } \\
\text { Swarm } \\
\text { Optimisation }\end{array}$ & $\begin{array}{l}\text { Dissimilar cost of PMU } \\
\text { allocations }\end{array}$ & $\begin{array}{l}\text { It was assumed that PMUs } \\
\text { capacity is limitless. PMU } \\
\text { channels limit was not } \\
\text { considered }\end{array}$ & $\begin{array}{l}\text { Taking consideration of } \\
\text { real-time equipping cost of } \\
\text { PMUs, limiting entire cost } \\
\text { in place of the quantity of } \\
\text { PMUs }\end{array}$ \\
\hline $\begin{array}{l}\text { B. Rohit and B. } \\
\text { Biplab [46] }\end{array}$ & $\begin{array}{l}\text { Reducing the number of meters and PMUs } \\
\text { Taking consideration of one line/meter } \\
\text { loss and one line/PMU loss }\end{array}$ & $\begin{array}{l}\text { Biogeography } \\
\text { Based } \\
\text { Optimisation }\end{array}$ & $\begin{array}{l}\text { Zero-injection nodes, } \\
\text { line loss, SCADA meter } \\
\text { loss, PMU the outage, } \\
\text { PMU/branch loss }\end{array}$ & $\begin{array}{l}\text { Traditional measurements, } \\
\text { PMU failure, Branch loss } \\
\text { was not considered }\end{array}$ & $\begin{array}{l}\text { using simulated node } \\
\text { reduction method for } \\
\text { decreasing the size of the } \\
\text { network }\end{array}$ \\
\hline $\begin{array}{l}\text { M. Hurtgen and J.- } \\
\text { C. Maun. [28] }\end{array}$ & $\begin{array}{l}\text { Reducing the overall quantity of PMUs } \\
\text { utilising PageRank placement technique } \\
\text { and iterated local search }\end{array}$ & $\begin{array}{l}\text { Iterated Local } \\
\text { Search }\end{array}$ & PMU outage & $\begin{array}{lr}\text { Zero-injection } & \text { nodes } \\
(\text { ZIN)\& } & \text { Measurement } \\
\text { Redundancy was not } \\
\text { considered }\end{array}$ & $\begin{array}{lr}\text { Taking consideration of } \\
\text { eventualities, } & \text { simple } \\
\text { comprehension } & \text { and } \\
\text { implementation } & \end{array}$ \\
\hline $\begin{array}{l}\text { S. S. Noureen, V. } \\
\text { Roy and S. B. } \\
\text { Bayne. [8] }\end{array}$ & $\begin{array}{l}\text { Limiting the quantity of PMUs. Observing } \\
\text { guide nodes needed for secondary voltage } \\
\text { control }\end{array}$ & $\begin{array}{l}\text { Branch and } \\
\text { Bound }\end{array}$ & \begin{tabular}{lr} 
Zero-injection & nodes \\
enhancement & of \\
secondary & voltage \\
\multicolumn{2}{c}{ control operation }
\end{tabular} & $\begin{array}{l}\text { PMU outage, branch loss, } \\
\text { measurements redundancy, } \\
\text { considered }\end{array}$ & $\begin{array}{l}\text { Observing guide nodes for } \\
\text { boosting speed of the } \\
\text { voltage control system }\end{array}$ \\
\hline $\begin{array}{l}\text { Y. Zhao, P. Yuan, Q. } \\
\text { Ai and T. Lv [22] }\end{array}$ & $\begin{array}{l}\text { Reducing the quantity of PMUs to monitor } \\
\text { both the overall network and fault in the } \\
\text { power network }\end{array}$ & $\begin{array}{l}\text { Differential } \\
\text { evolution }\end{array}$ & $\begin{array}{l}\text { Fault monitoring, Zero- } \\
\text { injection nodes }\end{array}$ & 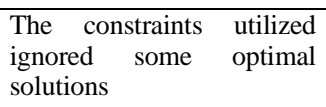 & $\begin{array}{l}\text { Utilising PMUs for power } \\
\text { network monitoring and } \\
\text { fault detection }\end{array}$ \\
\hline
\end{tabular}




\begin{tabular}{|c|c|c|c|c|c|}
\hline $\begin{array}{l}\text { S. S. Noureen, V. } \\
\text { Roy and S. B. Bayne } \\
\text { [8] }\end{array}$ & $\begin{array}{l}\text { Limiting means square error by achieving } \\
\text { the least quantity of PMUs }\end{array}$ & $\begin{array}{l}\text { Differential } \\
\text { evolution }\end{array}$ & $\begin{array}{l}\text { Taking consideration of } \\
\text { incessant alterations in } \\
\text { the power network's } \\
\text { topology }\end{array}$ & $\begin{array}{l}\text { Fault monitoring, ZIN was } \\
\text { ignored }\end{array}$ & $\begin{array}{l}\text { Integrating PMU allocation } \\
\text { problem into state estimate. }\end{array}$ \\
\hline $\begin{array}{l}\text { A. Ahmadi, Y. } \\
\text { Alinejad-Beromi } \\
\text { and M. Moradi [16] }\end{array}$ & $\begin{array}{l}\text { Limiting the quantity of PMUs, } \\
\text { recommending new the rule for the } \\
\text { network to be observed topologically }\end{array}$ & $\begin{array}{l}\text { Modified } \\
\text { binary particle } \\
\text { swarm } \\
\text { optimisation }\end{array}$ & $\begin{array}{l}\text { Zero-injection nodes, } \\
\text { PMU/Branch loss }\end{array}$ & $\begin{array}{l}\text { Measurement redundancy } \\
\text { was not studied, and the } \\
\text { problem of local least } \\
\text { affected the results }\end{array}$ & $\begin{array}{l}\text { Establishing new rules of } \\
\text { topologically Observable } \\
\text { valuation for limiting the } \\
\text { quantity of the needed } \\
\text { PMUs }\end{array}$ \\
\hline $\begin{array}{l}\text { H. Mohammadi, G. } \\
\text { Khademi, D. Simon } \\
\text { and M. Dehghani } \\
{[34]}\end{array}$ & $\begin{array}{l}\text { Two contending purposes involving the } \\
\text { least quantity of PMU and maximum } \\
\text { redundancy }\end{array}$ & $\begin{array}{l}\text { Multi- } \\
\text { objective } \\
\text { biogeography- } \\
\text { based } \\
\text { optimisation }\end{array}$ & $\begin{array}{l}\text { measurements } \\
\text { redundancies, } \quad \text { zero- } \\
\text { injection nodes. }\end{array}$ & $\begin{array}{l}\text { The large amount of cost } \\
\text { evaluations utilized made a } \\
\text { little difference in the } \\
\text { solution }\end{array}$ & $\begin{array}{l}\text { The proposed technique } \\
\text { generates well-circulated } \\
\text { Pareto-optimal solutions }\end{array}$ \\
\hline $\begin{array}{l}\text { M. Nazari-Heris and } \\
\text { B. Mohammadi- } \\
\text { Ivatloo [4] }\end{array}$ & $\begin{array}{l}\text { Multi-objective model, reducing the } \\
\text { quantity of PMUs and increasing } \\
\text { measurements }\end{array}$ & $\begin{array}{l}\text { Genetic } \\
\text { algorithm }\end{array}$ & $\begin{array}{l}\text { Considering single } \\
\text { branch/single PMU loss } \\
\text { considered }\end{array}$ & $\begin{array}{l}\text { ZIN enhancement of } \\
\text { secondary voltage control } \\
\text { operation was not ignored }\end{array}$ & $\begin{array}{l}\text { Very little population and } \\
\text { iterations needed are less }\end{array}$ \\
\hline $\begin{array}{l}\text { L. Qiao, C. Tao, W. } \\
\text { Yang, N. Rohit, F. } \\
\text { Franz and M. D. Ilić } \\
{[30]}\end{array}$ & $\begin{array}{l}\text { Reducing the quantity of PMUs utilising } \\
\text { anInfo-theoretic approach }\end{array}$ & $\begin{array}{l}\text { Mutual } \\
\text { information }\end{array}$ & $\begin{array}{l}\text { PMU outage, standard } \\
\text { measurement }\end{array}$ & ZIN was not considered & $\begin{array}{ll}\text { Modelling } & \text { the } \\
\text { improbabilities in } \\
\text { network states }\end{array}$ \\
\hline $\begin{array}{l}\text { A. Bashian, M. } \\
\text { Assili, A. Anvari- } \\
\text { Moghaddam and O. } \\
\text { R. Marouzi [11] }\end{array}$ & $\begin{array}{l}\text { Reducing the quantity of PMUs needed for } \\
\text { a total observable network and increasing } \\
\text { measurements redundancy. } \\
\text { topologically observable rule of zero- } \\
\text { injection nodes is also presented }\end{array}$ & $\begin{array}{l}\text { Binary } \\
\text { imperialistic } \\
\text { completion } \\
\text { algorithm }\end{array}$ & $\begin{array}{l}\text { PMU outage, branch } \\
\text { loss, measurements } \\
\text { redundancy, }\end{array}$ & $\begin{array}{l}\text { Cost considering ZIN was } \\
\text { ignored }\end{array}$ & $\begin{array}{l}\text { Quick integration, less } \\
\text { deviance, competence of } \\
\text { locating global optimal and } \\
\text { zero standard deviation }\end{array}$ \\
\hline $\begin{array}{l}\text { S. Li and Z. Meng } \\
\text { [37] }\end{array}$ & $\begin{array}{l}\text { Artificial bee colony technique is } \\
\text { implemented to attain least Quantity of } \\
\text { PMUs to achieve total observability of the } \\
\text { power network, a fitting measurement } \\
\text { redundancy }\end{array}$ & $\begin{array}{l}\text { Artificial bee } \\
\text { colony }\end{array}$ & $\begin{array}{l}\text { One branch loss and } \\
\text { Zero-injection nodes }\end{array}$ & $\begin{array}{l}\text { The technique in this study } \\
\text { was only tested on small } \\
\text { scale network }\end{array}$ & $\begin{array}{l}\text { Viability and performance } \\
\text { of the technique validated } \\
\text { by comparison of the } \\
\text { simulation outcomes with } \\
\text { the related previous } \\
\text { research }\end{array}$ \\
\hline
\end{tabular}

Table 2: Comparison of Conventional and Heuristic Technique

\begin{tabular}{|l|l|l|l|}
\hline S/N & Properties & Conventional Technique & Heuristic Technique \\
\hline 1 & $\begin{array}{l}\text { Size of the } \\
\text { Problem }\end{array}$ & $\begin{array}{l}\text { Usually, the conventional technique is utilised to } \\
\text { model a network when the network is not so } \\
\text { complex. }\end{array}$ & $\begin{array}{l}\text { Heuristic technique is a form of computation which tries to } \\
\text { mimic human or animal capability in a very simplified manner } \\
\text { in order to proffer solution to the problem of PMU allocation }\end{array}$ \\
\hline 2 & $\begin{array}{l}\text { Data } \\
\text { requirement }\end{array}$ & $\begin{array}{l}\text { The conventional method utilises physical } \\
\text { principles to obtain network relationships, which } \\
\text { are typically rightfully generalised with several } \\
\text { assumptions and need a previous understanding } \\
\text { of the nature of the data relationships. }\end{array}$ & $\begin{array}{l}\text { The heuristic technique focuses on data based on the data only } \\
\text { to decide the framework and variables to solve a network } \\
\text { problem, with fewer assumptions about the network's nature. }\end{array}$ \\
\hline 3 & Accuracy & $\begin{array}{l}\text { As compared to Heuristic technique, because of } \\
\text { several factors implemented, the conventional } \\
\text { technique does not have a better degree of } \\
\text { correctness. }\end{array}$ & $\begin{array}{l}\text { Owing to very little possibilities of failure, Heuristic technique } \\
\text { has higher precision. }\end{array}$ \\
\hline 4 & Effectiveness & $\begin{array}{l}\text { The conventional technique takes more } \\
\text { computational time when compared with } \\
\text { Heuristic techniques to solve a complicated } \\
\text { network problem. }\end{array}$ & $\begin{array}{l}\text { The heuristic technique can be used effectively in performing } \\
\text { routine and tasks that consume time. }\end{array}$ \\
\hline
\end{tabular}

\section{Results}

According to the comparison in Table 2, heuristic technique did better in terms of complexity of the network, data requirement, and level of correctness and effectiveness as regards to time. For this research genetic algorithm is selected the optimization solver for optimal placement of PMUs on IEEE14, 30 and Nigerian $330 \mathrm{KV}$ ( 28 and 52 bus system) networks. It was selected in place of other heuristic algorithms because it is one of the pioneer evolutionary algorithms, simplicity and ease of implementation, and logical reasoning behind the use of operators like selection, crossover and mutation. The mutation operator is executed bit by bit after offspring is produced, for every node in the chromosome expression, an evenly appropriated random number is created between zero and one. If the number produced is lower than the likelihood of the mutation, then the corresponding bit will be 
modified from zero to one or one to zero, thereby putting or eliminating the PMU on the appropriate node. Once all the offspring have been generated, the current population and the created offspring are categorized based on the decreasing order of the objective function provided, and a tournament selection is carried out to determine the new generation. Again, a difference is made based on the size on the problem, the top 10 chromosomes are chosen to utilize the tournament selection scheme and inserted directly into the current generation. The suggested approach is implemented to find a solution to the problem by taking consideration of these cases: Normal operation; and Case considering Zero Injection (ZIN)

\subsection{Normal operation}

In this case, the solution for the optimal PMU placement problem is obtained by ignoring ZIN.

Table 3: Normal operation

\begin{tabular}{|l|l|l|l|l|}
\hline & IEEE14 & $\begin{array}{l}\text { IEEE } \\
\mathbf{3 0}\end{array}$ & NG 28 & NG 52 \\
\hline $\begin{array}{l}\text { Number } \\
\text { of PMU }\end{array}$ & 4 & 10 & 11 & 17 \\
\hline $\begin{array}{l}\text { PMU } \\
\text { location } \\
\text { Bus } \\
\text { number }\end{array}$ & $2,6,7,9$ & $\begin{array}{l}1,5,8,12, \\
19,23,\end{array}$ & $\begin{array}{l}1,3,4,17,20,29, \\
21,24,24,4,6,8,10, \\
27\end{array}$ & $\begin{array}{l}16,19,24,26, \\
42,35,39,\end{array}$ \\
\hline
\end{tabular}

Table 3 shows PMU placement result for the IEEE 14, IEEE 30 , Nigeria bus 28 and 52 considering normal arrangement of the bus.

\subsection{Case considering ZIN}

In this case, the solution for the optimal PMU placement problem is obtained by considering ZIN.

Table 4: Locations of the ZINs

\begin{tabular}{|l|l|}
\hline Bus & Zero Injection location \\
\hline IEEE-14 & 7 \\
\hline IEEE-30 & $6,9,22,25,27,28$ \\
\hline NG-28 & 11 \\
\hline NG-52 & - \\
\hline
\end{tabular}

Table 4 shows the location of the zero-injection node for each bus considered.

Table 5: Considering Zero Injection Node

\begin{tabular}{|l|c|c|l|l|}
\hline & IEEE14 & IEEE 30 & NG 28 & NG 52 \\
\hline $\begin{array}{l}\text { Number } \\
\text { of PMU }\end{array}$ & 3 & 7 & 10 & N/A \\
\hline $\begin{array}{l}\text { Bus PMU } \\
\text { location }\end{array}$ & $2,6,9$ & $\begin{array}{l}1,2, \quad 10,19,23, \\
27\end{array}$ & $\begin{array}{l}1,3,4,12, \\
17,20,21, \\
23,24,27\end{array}$ & N/A \\
\hline
\end{tabular}

Table 5 shows PMU placement results for the IEEE 14, IEEE 30 , Nigeria bus 28 , and 52 considering zero injection node. When a zero-injection node is considered, the number of PMUs needed to observe a system is reduced because that particular bus is merged with a connecting node.

Table 6: System of Redundancy Index (SORI)

\begin{tabular}{|l|l|l|l|}
\hline Bus & GA & ILP [54] & IQP [55] \\
\hline IEEE14 & $\begin{array}{l}\text { NPMU: 4 } \\
\text { SORI: 19 }\end{array}$ & $\begin{array}{l}\text { NPMU: 4 } \\
\text { SORI: 19 }\end{array}$ & $\begin{array}{l}\text { NPMU: 4 } \\
\text { SORI: 19 }\end{array}$ \\
\hline IEEE 30 & $\begin{array}{l}\text { NPMU: 10 } \\
\text { SORI: 52 }\end{array}$ & $\begin{array}{l}\text { NPMU: 10 } \\
\text { SORI: 50 }\end{array}$ & $\begin{array}{l}\text { NPMU: 10 } \\
\text { SORI: 50 }\end{array}$ \\
\hline NG 28 & $\begin{array}{l}\text { NPMU: 11 } \\
\text { SORI: 46 }\end{array}$ & N/A & N/A \\
\hline NG 52 & $\begin{array}{l}\text { NPMU: 17 } \\
\text { SORI: 71 }\end{array}$ & N/A & N/A \\
\hline
\end{tabular}

Table 6 shows a benchmark with previous studies that utilized a mathematical method considering a normal operation. The result is favourably compared with the previous work carried out on IEEE 14 and IEEE 30 bus system. However, the result obtained in this study is superior to the mathematical methods since it gives the same number of PMU and a higher quality of SORI. Based on this fact, Genetic Algorithm is recommended and is adequately fit heuristic technique for PMU placement which improved resilience of the system and enhanced its reliability.

\section{Conclusion}

The problem of placing PMU optimally was solved using GA heuristic technique and the quality of the result was compared to results of previous research, from the comparison as shown in the result, it can be observed that the system of redundancy index for the heuristic algorithm used did better than the mathematical programming method when implemented on the IEEE 30 bus system, and achieved the same quality for the IEEE 14 bus system. Methods such as conventional and heuristic techniques, exist to solve the optimal placement problems; this study presented a thorough review study on both techniques. Stabilisation and control of Optimal PMU Placement (OPP) have become a power network necessity. We covered a magnificent set of techniques in this study. This would give researchers a structure for classifying these methods and choosing the appropriate solution prior to applying for PMU placement. Analysis of optimisation techniques in this research shows that minimising the OPP would be a framework and help identify optimisation conditions for projections in time to come.

\section{Conflict of Interest}

The authors declare no conflict of interest.

\section{Acknowledgment}

This research work and publication charge is fully funded by Covenant University Centre for Research, Innovation and Discovery (CUCRID). 


\section{References}

[1] A.G. Phadke, "Synchronized Phase Measurement in Power System," IEEE Computer Applications in Power, 6(2), 10-15, 1993, doi:10.1109/67.207465.

[2] P.O. Oluseyi, T.E. Somefun, O.M. Babatunde, T.O. Akinbulire, O.O. Babayomi, S.A. Isaac, D.E. Babatunde, "Evaluation of energy-efficiency in lighting systems for public buildings," International Journal of Energy Economics and Policy, 10(6), 2020, doi:10.32479/ijeep.9905.

[3] N. Rahman, A.F. Zobaa, "Optimal PMU placement using topology transformation method in power systems," Journal of Advanced Research, 7(5), 625-634, 2016, doi:10.1016/j.jare.2016.06.003.

[4] M. Nazari-Heris, B. Mohammadi-Ivatloo, Application of heuristic algorithms to optimal PMU placement in electric power systems: An updated review, Renewable and Sustainable Energy Reviews, 2015, doi:10.1016/j.rser.2015.04.152.

[5] T.E. Somefun, C.O.A. Awosope, A. Abdulkareem, A.S. Alayande, "Deployment of power network structural topology to optimally position distributed generator within distribution system," Journal of Engineering Science and Technology Review, 13(1), 2020, doi:10.25103/jestr.131.2.

[6] T.S. Shomefun, A. Ademola, C.O.A. Awosope, A.I. Adekitan, "Critical review of different methods for siting and sizing distributed-generators," Telkomnika (Telecommunication Computing Electronics and Control), 16(5), 2018, doi:10.12928/TELKOMNIKA.v16i5.9693.

[7] S.P. Singh, A.K. Thakur, S.P. Singh, "PMU Placement for Maximum Observability of Power System under Different Contingencies," in Energy Procedia, 2017, doi:10.1016/j.egypro.2017.05.208.

[8] S.S. Noureen, V. Roy, S.B. Bayne, "Phasor measurement unit integration: A review on optimal PMU placement methods in power system," in 5th IEEE Region 10 Humanitarian Technology Conference 2017, R10-HTC 2017, 2018, doi:10.1109/R10-HTC.2017.8288967.

[9] Y. Xueliang, Z. Hengxu, J. Cao, "Analysis of influencing factors in hybrid state estimation," in Asia-Pacific Power and Energy Engineering Conference, APPEEC, 2016, doi:10.1109/APPEEC.2016.7779892.

[10] N. Xie, F. Torelli, E. Bompard, A. Vaccaro, "A graph theory based methodology for optimal PMUs placement and multiarea power system state estimation," Electric Power Systems Research, 2015, doi:10.1016/j.epsr.2014.08.023.

[11] A. Bashian, M. Assili, A. Anvari-Moghaddam, O.R. Marouzi, "Co-optimal PMU and communication system placement using hybrid wireless sensors," Sustainable Energy, Grids and Networks, 2019, doi:10.1016/j.segan.2019.100238.

[12] Z. Zhao, H. Yu, P. Li, X. Kong, J. Wu, C. Wang, "Optimal placement of PMUs and communication links for distributed state estimation in distribution networks," Applied Energy, 2019, doi:10.1016/j.apenergy.2019.113963.

[13] P.P. Bedekar, S.R. Bhide, V.S. Kale, "Optimum PMU placement considering one line/one PMU outage and maximum redundancy using genetic algorithm," in ECTI-CON 2011 - 8th Electrical Engineering/ Electronics, Computer, Telecommunications and Information Technology (ECTI) Association of Thailand - Conference 2011, 2011, doi:10.1109/ECTICON.2011.5947933.

[14] R. Babu, B. Bhattacharyya, "Optimal allocation of phasor measurement unit for full observability of the connected power network," International Journal of Electrical Power and Energy Systems, 2016, doi:10.1016/j.ijepes.2016.01.011.

[15] M. Shafiullah, M.I. Hossain, M.A. Abido, T. Abdel-Fattah, A.H. Mantawy, "A modified optimal PMU placement problem formulation considering channel limits under various contingencies," Measurement: Journal of the International Measurement Confederation, 2019, doi:10.1016/j.measurement.2018.12.039.

[16] A. Ahmadi, Y. Alinejad-Beromi, M. Moradi, "Optimal PMU placement for power system observability using binary particle swarm optimization and considering measurement redundancy," Expert Systems with Applications, 2011, doi:10.1016/j.eswa.2010.12.025.

[17] C. Lu, Z. Wang, Y. Yu, "Optimal PMU placement for pessimistic dynamic vulnerability assessment," IET Generation, Transmission and Distribution, 2018, doi:10.1049/iet-gtd.2017.1261.

[18] Q. Xu, L. Yu, Y. Wang, X. Kong, X. Yuan, "Optimal PMU Placement for the Distribution System Based on Genetic-Tabu Search Algorithm," in 2019 IEEE PES Innovative Smart Grid Technologies Asia, ISGT 2019, 2019, doi:10.1109/ISGT-Asia.2019.8881465.

[19] N.C. Koutsoukis, N.M. Manousakis, P.S. Georgilakis, G.N. Korres, "Numerical observability method for optimal phasor measurement units placement using recursive tabu search method," IET Generation,
Transmission and Distribution, 2013, doi:10.1049/iet-gtd.2012.0377.

[20] A. Yda Amira, G. Fathi, A. Amira, G.F.-M.-C. on Systems, \& S., U. 2011, "Optimal PMU placement for full network observability case of the tunisian network," Ieeexplore.Ieee.Org, 1-5, 2011, doi:10.1109/ssd.2011.5986789.

[21] S.S.M. Nosratabadi, J. Modarresi, J.M.-2017 S.G. Conference, undefined 2017, "Phasor measurement units placement considering double contingency by differential evolution algorithm based on pareto method," Ieeexplore.Ieee.Org, 2018-Janua, $\quad 1-6, \quad 2018$, doi:10.1109/SGC.2017.8308885.

[22] Y. Zhao, P. Yuan, Q. Ai, T. Lv, \& T.L.-I.J. of E.P., U. 2015, “Optimal PMU placement considering topology constraints," Elsevier, 73, 240-248, 2015, doi:10.1016/j.ijepes.2015.04.022.

[23] B. Mallikarjuna, P. Gopakumar, M.J.B. Reddy, D.K. Mohanta, “A case study on optimal phasor measurement unit placement for emerging Indian national smart grid," in International Conference on Signal Processing, Communication, Power and Embedded System, SCOPES 2016 Proceedings, Institute of Electrical and Electronics Engineers Inc.: 19561960, 2017, doi:10.1109/SCOPES.2016.7955789.

[24] S. Akhlaghi, "Optimal PMU placement considering contingency-constraints for power system observability and measurement redundancy," in IEEE Power and Energy Conference at Illinois (PECI), Urbana, IL, USA, IEEE:, 2016, doi:10.1109/PECI.2016.7459251.

[25] A.Y. Abdelaziz, H.A. Abdelsalam, V. Mukherjee, "Optimal PMU Placement in a Distribution Network Considering Network Reconfiguration," Ieeexplore.Ieee.Org, 2015, doi:10.1109/ICCPCT.2014.7054997.

[26] B.K.S. Roy, A.K. Sinha, A.K. Pradhan, "Optimal phasor measurement unit placement for power system observability - A heuristic approach," in IEEE SSCI 2011 - Symposium Series on Computational Intelligence - CIASG 2011: 2011 IEEE Symposium on Computational Intelligence Applications in Smart Grid, 77-82, 2011, doi:10.1109/CIASG.2011.5953335.

[27] R. Salem, A.Y. Abdelaziz, A.M. Ibrahim, R.H. Salem, Optimal PMU Placement for Complete Observability Using Heuristic Methods, 2012.

[28] M. Hurtgen, J.C. Maun, "Optimal PMU placement using Iterated Local Search," International Journal of Electrical Power and Energy Systems, 32(8), 857-860, 2010, doi:10.1016/j.ijepes.2010.01.028.

[29] S. Chakrabarti, E. Kyriakides, "Optimal Placement of Phasor Measurement Units for Power System Observability," IEEE TRANSACTIONS ON POWER SYSTEMS, 23(3), 1433, 2008, doi:10.1109/TPWRS.2008.922621.

[30] Q. Li, T. Cui, Y. Weng, R. Negi, F. Franchetti, M.D. Ilic, "An informationtheoretic approach to PMU placement in electric power systems," IEEE Transactions on Smart Grid, 4(1), 446-456, 2013, doi:10.1109/TSG.2012.2228242.

[31] M. Zhou, V.A. Centeno, A.G. Phadke, Y. Hu, D. Novosel, H.A.R. Volskis, "A preprocessing method for effective PMU placement studies," in 3rd International Conference on Deregulation and Restructuring and Power Technologies, DRPT 2008, 2862-2867, 2008, doi:10.1109/DRPT.2008.4523897.

[32] A. Ghasemkhani, A. Anvari-Moghaddam, J.M. Guerrero, B. Bak-Jensen, "An Efficient Multi-objective Approach for Designing of Communication Interfaces in Smart Grids," Ieeexplore.Ieee.Org, Nov. 2020, doi:10.1109/ISGTEurope.2016.7856286.

[33] S. Mahapatra, S. Panda, S.C. Swain, "A hybrid firefly algorithm and pattern search technique for SSSC based power oscillation damping controller design," Ain Shams Engineering Journal, 5(4), 1177-1188, 2014, doi:10.1016/j.asej.2014.07.002.

[34] H. Mohammadi, G. Khademi, D. Simon, M. Dehghani, Multi-Objective Optimization of Decision Trees for Power System Voltage Security Assessment, Nov. 2020, doi:10.1109/SYSCON.2016.7490524.

[35] M.H.F. Wen, J. Xu, V.O.K. Li, "Optimal Multistage PMU Placement for Wide-Area Monitoring," IEEE TRANSACTIONS ON POWER SYSTEMS, 28(4), 2013, doi:10.1109/TPWRS.2013.2277741.

[36] J. Xu, M.H.F. Wen, V.O.K. Li, K.C. Leung, "Optimal PMU placement for wide-area monitoring using chemical reaction optimization," in 2013 IEEE PES Innovative Smart Grid Technologies Conference, ISGT 2013, 2013, doi:10.1109/ISGT.2013.6497845.

[37] S. Li, Z. Meng, "Optimal PMU placement based on improved binary artificial bee colony algorithm," in 2017 IEEE Transportation Electrification Conference and Expo, Asia-Pacific, ITEC Asia-Pacific 2017, Institute of Electrical and Electronics Engineers Inc., 2017, doi:10.1109/ITECAP.2017.8081008.

[38] P.K. Ghosh, "Complete and incomplete PMU observablity for hybrid state estimation," in 6th International Conference on Computation of Power, Energy, Information and Communication, ICCPEIC 2017, Institute of Electrical and Electronics Engineers Inc.: 867-870, 2018, doi:10.1109/ICCPEIC.2017.8290487. 
[39] S. Mahdi Mazhari, S. Member, H. Monsef, H. Lesani, A. Fereidunian, “A Multi-Objective PMU Placement Method Considering Measurement Redundancy and Observability Value Under Contingencies," Ieeexplore.Ieee.Org, 2013, doi:10.1109/TPWRS.2012.2234147.

[40] B. Ozsoy, M. Gol, "A Hybrid State Estimation Strategy with Optimal Use of Pseudo-Measurements," in Proceedings - 2018 IEEE PES Innovative Smart Grid Technologies Conference Europe, ISGT-Europe 2018, Institute of Electrical and Electronics Engineers Inc., 2018, doi:10.1109/ISGTEurope.2018.8571513.

[41] M.M. Rezaoui, D. Ridha, A.A. Laouid, A. Kouzou, R.D. Mohammedi, "Optimal PMUs Placement Using Hybrid PSO-GSA Algorithm," Ieeexplore.Ieee.Org, 25-27, 2019, doi:10.1109/ICPEA1.2019.8911178.

[42] M. Carvalho, X. Klimentova, A. Viana, "Observability of power systems with optimal PMU placement," Computers and Operations Research, 96, 330-349, 2018, doi:10.1016/j.cor.2017.10.012.

[43] C. Peng, H. Sun, J. Guo, "Multi-objective optimal PMU placement using a non-dominated sorting differential evolution algorithm," International Journal of Electrical Power and Energy Systems, 32(8), 886-892, 2010, doi:10.1016/j.ijepes.2010.01.024.

[44] R. Ramachandran, S. Karthick, "Optimal PMU Placement for Tamil Nadu Grid Under Controlled Islanding Environment," Procedia Technology, 21, 240-247, 2015, doi:10.1016/j.protcy.2015.10.021.

[45] B. Rohit, B. Biplab, "Optimal Placement of Phasor Measurement Unit using Binary Particle Swarm Optimization in Connected Power Network," in 2015 IEEE UP Section Conference on Electrical Computer and Electronics (UPCON), IEEE, Allahabad, India: 1-5, 2015, doi:10.1109/UPCON.2015.7456695.

[46] K. Jamuna, Y.L. Selva, G. Gnanasekaran, "Placement of PMUs for power system observability using biogeography based optimization," in Proceedings - 2013 3rd International Conference on Advances in Computing and Communications, ICACC 2013, 355-358, 2013, doi:10.1109/ICACC.2013.76. 